\title{
EMERGENCY OR DELAYED SURGICAL TREATMENT OF UNSTABLE SUPRACONDYLAR HUMERAL FRACTURES IN CHILDREN?
}

Branko Stefanovic ${ }^{1}$, Zoran Vukasinovic ${ }^{1}$, Srbobran Stankovic ${ }^{2}$, Jovana Jeremic ${ }^{3}$, Nevena Jeremic ${ }^{3}$, Isidora Stojic ${ }^{3}$ ${ }^{1}$ Institute for Orthopaedic Surgery "Banjica”, Belgrade, Serbia ${ }^{2}$ Health Centre "Rakovica", Belgrade, Serbia

${ }^{3}$ Department of Pharmacy, Faculty of Medical Sciences, University of Kragujevac, Kragujevac, Serbia

\author{
HITANA ILI ODLOŽENA HIRURŠKA INTERVENCIJA NESTABILNOG \\ SUPRAKONDILARNOG PRELOMA HUMERUSA KOD DECE? \\ Branko Stefanović1, Zoran Vukašinović ${ }^{1}$, Srbobran Stanković ${ }^{2}$, Jovana Jeremić ${ }^{3}$, Nevena Jeremić ${ }^{3}$, Isidora Stojić ${ }^{3}$ \\ ${ }^{1}$ Institut za ortopedsko-hirurške bolesti “Banjica”, Beograd, Srbija \\ ${ }^{2}$ Dom zdravlja Rakovica, Beograd, Srbija \\ ${ }^{3}$ Katedra za farmaciju, Fakultet medicinskih nauka, Kragujevac, Srbija
}

\begin{abstract}
Supracondylar humeral fractures (SCHF) are the most common elbow fractures in children, representing 3\% of all paediatric fractures. Treatment options for SCHF in children are based on the Gartland classification. Treatment of non-displaced fractures (type I) is non-operative. Plaster immobilization for 3 to 4 weeks is recommended, depending on the age of the child and fracture healing. Treatments of displaced supracondylar fractures (type II and III) of the humerus in children are still undefined in clinical practice. Because of divided opinions, the aim of this study was to evaluate whether delayed or immediate surgical treatment has an advantage in the treatment of supracondylar fractures in children. This is a prospective - retrospective clinical study. This study included 64 patients from 5 to 15 years old; 47 (73.4\%) were boys and 17 (26.6\%) were girls. The most common age range (59.4\%) in this study was 5-8 years old. All patients were diagnosed with supracondylar fractures at the Institute for Orthopaedic Surgery "Banjica". We analysed 17 parameters, which were obtained either from direct patient interviews or from their medical history. All patients were divided into two groups with matched characteristics. Group I consisted of 26 patients who had immediate operations. Group II consisted of 38 patients who had delayed operations.

Based on the results of the analysed parameters, consisting primarily of functional results, the absence of subjective symptoms and myositis ossificans one year after surgery suggests that emergency surgical treatment of displaced supracondylar humeral fractures is optimal.
\end{abstract}

Key words: Supracondylar humeral fractures, Functional result, Myositis ossificans, Cubitus varus, Cubitus valgus.

\section{SAŽETAK}

Suprakondilarni prelomi humerusa su najčešći prelomi lakta kod dece i predstavljaju 3\% od svih pedijatrijskih preloma. Opcije za tretman ovog preloma kod dece, zasnovane su na Gartland-ovoj klasifikaciji. Tretman nedislociranog preloma (tip I) je neoperativan. Većina autora preporučuje imobilizaciju gipsom 3 do 4 nedelje u zavisnosti od zarastanja i uzrasta deteta. Tretman dislociranog preloma (tip II $i$ tip III) još uvek nije univerzalno definisan. Upravo zbog podeljenih mišljenja, cilj ove studije bio je da ispita da li hitno ili odloženo hirurško lečenje ima prednsti u tretmanu suprakondilarnog preloma kod dece. Ovo je bila prospektivno-retrospektivna klinička studija. U studiji je učestvovalo 64 pacijenata od 5 do 15 godina, 47 (73,4\%) dečaka $i$ 17 (26,6\%) devojčica. Većina (59,4\%) pacijenata u studiji imala je od 5 do 8 godina. Svim pacijentima dijagnostikovana je suprakondilarna fraktura na Institutu za ortopediju "Banjica". Analizirano je 17 parametara, a same informacije su dobijene direktno od pacijenata ili iz medicinske istorije. Svi pacijenti su bili podeljeni u dve grupe sa sličnim karakteristikama. Grupu I sačinjavalo je 26 pacijenata koji su bili hitno operisani, a grupu II 38 pacijenata koji su imali odloženu operaciju.

Analizirani parametari, prvenstveno funkcionalni rezultati kao i prisustvo subjektivnih simptoma $i$ myositis ossificans-a, godinu dana nakon operacije, favorizuju hitno hirurško lečenje dislociranih suprakondilarnih preloma humerusa.

Ključne reči: Suprakondilarni prelom humerusa, Funkcionalni rezultati, Myositis ossificans, Cubitis varus, Cubitis valgus.

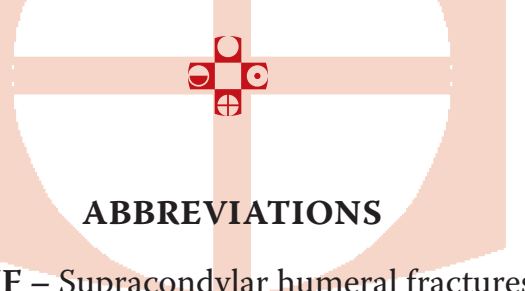

SCHF - Supracondylar humeral fractures 


\section{INTRODUCTION}

Supracondylar humeral fractures (SCHF) are the most common elbow fractures in children, representing 3\% of all paediatric fractures. The annual incidence of these fractures is estimated to be 177.3 per 100,000 children. They have a seasonal distribution, being more frequent in the summer months, and occur more often in the left elbow (1). Boys are more affected by this fracture than girls $(2,3)$ and the prevalence decreases after 12 years of age (4).

The elbow is a hinge joint formed by the distal humerus, radial head and proximal ulna. The distal humerus has two surfaces that articulate with both forearm bones. Specifically, the capitellum articulates with the radial head and the trochlea interacts with the articular surface of the olecranon. The elbow is a very complex anatomical area with many related structures. All these structures must be well understood by the paediatric orthopaedic surgeon for proper supracondylar fracture management (5). Supracondylar fractures of the humerus in children are fractures located at the distal end of the humerus, from the proximal end of the distal metaphysis to the distal transversal humeral shaft (6).

SCHF are classified into two types, according to the mechanism of injury. The flexion type is present in only $2 \%$, whereas the extension type is present in $98 \%$ of all injuries. In extension fractures, the Gartland classification is used to describe the severity of the injury as well as to focus therapeutic management. Such fractures are divided into three types, according to the degree of fracture displacement measured in the lateral view on a plain radiograph (7). Type I is very stable and includes non-displaced or minimally displaced fractures. Type II includes slight displacement fractures $(>2 \mathrm{~mm})$ with an intact posterior cortex. Type III includes completely displaced fractures. This type of fracture is unstable and requires operative treatment $(6,8)$.In extension type fractures, the mechanism of fracture involves a fall on the extended arm. In this type of fracture, the radial and median nerve and brachial artery are more prone to injury, while in flexion type fractures ulnar nerve injury is more likely (8). Radiographic diagnosis includes an anteroposterior view of the distal part of the humerus, an anteroposterior radiograph of the elbow and a lateral radiograph of the elbow. Initial radiographs may show no evidence of a non-displaced fracture, except signs of a posterior fat-pad. It is sometimes necessary to perform a radiographic diagnosis of the uninjured elbow to confirm the fracture in the injured elbow (7).

Treatment options for SCHF in children are based on the Gartland classification. Treatment of non-displaced fractures (type I) is non-operative. Plaster immobilization for 3 to 4 weeks is recommended, depending on the age of the child and fracture healing $(9,10)$. Treatments of displaced supracondylar fractures (type II and III) of the humerus in children are still undefined in clinical practice. Some authors defend a conservative approach to stable type II fractures without malrotation or displacement (11,
12) while the American Academy of Orthopaedic Surgeons (AAOS) has recommended surgical treatment for all type II fractures (13). All described treatments can be classified into 4 categories: orthopaedic repositioning, repeated orthopaedic repositioning, delayed surgical treatment in the case of unsatisfactory repositioning and emergency surgical treatment.

Because of divided opinions, the aim of this study was to evaluate whether delayed or immediate surgical treatment has an advantage in the treatment of supracondylar fractures in children.

\section{PATIENTS AND METHODS}

This is a prospective - retrospective clinical study. The study included 64 patients, whose ages ranged from 5 to 15 years old. All patients were diagnosed with supracondylar fractures at the Institute for Orthopaedic Surgery "Banjica". In the period between 1990 and 2007, data were obtained either from direct patient interviews or from their medical history.

The patients were characterized using the Gartland classification method. All patients in this study had surgery using either the posterior or lateral approach. The lateral approach was used more frequently. For fixation, Kirchner pins (two, three or four) were used. These were swiftly removed after 3 to 6 weeks. Exclusion criteria from the study included the following: Gartland type I fractures (non-displaced), open fractures and cases with serious neurovascular complications demanding other specific operative management.

All patients were divided into two groups. Group I consisted of 26 patients who had immediate operations (within two days after the fracture). Group II consisted of $38 \mathrm{pa}-$ tients who had delayed operations (at least two days after fracture). Patients were also divided into three groups by age: from 5 to 8 , from 9 to 12 and from 13 to 15 years old.

We analysed 17 parameters (7 numeric and 10 descriptive). Numeric parameters included the following: ages, tracking time (in months), days from fracture until operation, functional movement (in degrees), the Baumann's angle (before and after operation), humerocapitellar angle (before and after operation) and time to bone healing. Descriptive parameters included: sex, functional results after one year, continuous anterior humeral line (before and after operation), continuous coronoid line (before and after operation), nerve lesions (before and after operation), vascular complications (before and after operation), myositis ossificans, cubitus varus, cubitus valgus and subjective symptoms at the end of the monitoring period.

The most important parameter was the functional result of the elbow after one year. It was estimated by the Hardacre functional score and included the range of movement, presence of subjective complaints, deformity and radiographic changes (14). The results were described as excellent, good, satisfactory or poor. An excellent result 
Table 1. Patient characteristics

\begin{tabular}{|c|c|c|c|c|}
\hline & & \multicolumn{2}{|c|}{ Frequency } & Percentage \\
\hline \multirow{2}{*}{ Groups } & I & \multicolumn{2}{|c|}{26} & 40.6 \\
\hline & II & \multicolumn{2}{|c|}{38} & 59.4 \\
\hline \multirow{4}{*}{ Sex } & \multirow{2}{*}{ Male } & I & 19 & 29.7 \\
\hline & & II & 28 & 43.7 \\
\hline & \multirow{2}{*}{ Female } & I & 7 & 10.9 \\
\hline & & II & 10 & 15.7 \\
\hline \multirow{6}{*}{ Age } & \multirow{2}{*}{$5-8$ years } & I & 16 & 25 \\
\hline & & II & 22 & 34.4 \\
\hline & \multirow{2}{*}{$9-12$ years } & I & 7 & 10.9 \\
\hline & & II & 9 & 14.1 \\
\hline & \multirow{2}{*}{$13-15$ years } & I & 3 & 4.7 \\
\hline & & II & 7 & 10.9 \\
\hline
\end{tabular}

included a full range of motion in the elbow and no subjective problems and deformities, with the possibility of mild radiographic changes. A good result included less than the full range of movement, with a loss of less than 10 degrees for each movement or changes in the humeral corner of the elbow with some radiographic changes but without subjective problems and deformities. A satisfactory result included a loss of 10 to 20 degrees for each movement, changes in the humeral corner of the elbow of more than 5 degrees without deformities and with or without subjective problems. A poor result included loss of more than 20 degrees from each movement and changes in the humeral corner of the elbow outside the normal range with subjective problems and deformities.

Statistical analyses were performed using the statistical package SPSS 20.0 for Windows. The results are expressed as the means \pm standard deviations from the mean (SD). Data distribution was checked with the T-test, $\mathrm{x}^{2}$-test, analysis of variance, the Fisher and Kruskal-Wallis test and descriptive statistical methods. The alpha level for significance was set to $\mathrm{p}<0.05$.

Table 2. Fracture characteristics before and after operation for both groups

\begin{tabular}{|c|c|c|c|c|c|}
\hline & & & Frequency & Percentage & Cumulative percentage \\
\hline \multirow{4}{*}{ Functional result $^{\#}$} & \multicolumn{2}{|l|}{ Poor } & 6 & 9.4 & 9.4 \\
\hline & \multicolumn{2}{|c|}{ Satisfactory } & 12 & 18.8 & 28.1 \\
\hline & \multicolumn{2}{|l|}{ Good } & 17 & 26.6 & 54.7 \\
\hline & \multicolumn{2}{|c|}{ Excellent } & 24 & 45.3 & 100.0 \\
\hline \multirow{4}{*}{$\begin{array}{l}\text { Continuous anterior } \\
\text { humeral line }\end{array}$} & \multirow{2}{*}{ Before operation } & No & 63 & 98.4 & 98.4 \\
\hline & & Yes & 63 & 1.6 & 100.0 \\
\hline & \multirow{2}{*}{ After operation } & No & 14 & 21.9 & 21.9 \\
\hline & & Yes & 50 & 78.1 & 100.0 \\
\hline \multirow{4}{*}{$\begin{array}{l}\text { Continuous coronoid } \\
\text { line }\end{array}$} & \multirow{2}{*}{ Before operation } & No & 58 & 90.6 & 90.6 \\
\hline & & Yes & 6 & 9.4 & 100.0 \\
\hline & \multirow{2}{*}{ After operation } & No & 4 & 6.3 & 6.3 \\
\hline & & Yes & 60 & 93.8 & 100.0 \\
\hline \multirow{4}{*}{ Nerve lesions } & \multirow{2}{*}{ Before operation } & No & 60 & 93.8 & 93.8 \\
\hline & & Yes & 4 & 6.3 & 100.0 \\
\hline & \multirow{2}{*}{ After operation } & No & 55 & 85.9 & 85.9 \\
\hline & & Yes & 9 & 14.1 & 100.0 \\
\hline \multirow{4}{*}{$\begin{array}{c}\text { Vascular } \\
\text { complications }\end{array}$} & \multirow{2}{*}{ Before operation } & No & 64 & 100.0 & 100.0 \\
\hline & & Yes & 1 & 1 & 1 \\
\hline & \multirow{2}{*}{ After operation } & No & 63 & 98.4 & 98.4 \\
\hline & & Yes & 1 & 1.6 & 100.0 \\
\hline \multirow{2}{*}{ Myositis ossificans } & \multicolumn{2}{|l|}{ No } & 51 & 79.7 & 79.7 \\
\hline & \multicolumn{2}{|l|}{ Yes } & 13 & 20.3 & 100.0 \\
\hline \multirow{2}{*}{ Cubitus varus ${ }^{\#}$} & \multicolumn{2}{|l|}{ No } & 56 & 87.5 & 87.5 \\
\hline & \multicolumn{2}{|l|}{ Yes } & 8 & 12.5 & 100.0 \\
\hline \multirow{2}{*}{ Cubitus valgus $\#$} & \multicolumn{2}{|l|}{ No } & 63 & 98.4 & 98.4 \\
\hline & \multicolumn{2}{|l|}{ Yes } & 1 & 1.6 & 100.0 \\
\hline \multirow{2}{*}{ Subjective symptoms } & \multicolumn{2}{|l|}{ No } & 42 & 65.6 & 65.6 \\
\hline & \multicolumn{2}{|l|}{ Yes } & 22 & 34.4 & 100.0 \\
\hline
\end{tabular}


Table 3. Differences between groups I and II before operation

\begin{tabular}{|c|c|c|c|c|}
\hline & & I & II & Difference frequency \\
\hline \multirow{2}{*}{ Continuous anterior humeral line } & No & 25 & 38 & \multirow{2}{*}{$\mathrm{p}>0.05$} \\
\hline & Yes & 1 & 0 & \\
\hline \multirow{2}{*}{ Continuous coronoid line } & No & 1 & 5 & \multirow{2}{*}{$\mathrm{p}>0.05$} \\
\hline & Yes & 25 & 33 & \\
\hline \multirow{2}{*}{ Nerve lesions } & No & 24 & 36 & \multirow{2}{*}{$\mathrm{p}>0.05$} \\
\hline & Yes & 2 & 2 & \\
\hline \multirow{2}{*}{ Vascular complications } & No & 26 & 38 & \multirow{2}{*}{ l } \\
\hline & Yes & l & l & \\
\hline Baumann's angle & & 4.50 & 1.29 & $\mathrm{p}>0.05$ \\
\hline Humerocapitellar angle & & -30.00 & -24.39 & $\mathrm{p}>0.05$ \\
\hline
\end{tabular}

\section{RESULTS}

The study included 64 patients, all of whom were followed for a minimum of 12 months. Forty-seven (73.4\%) of the patients were boys and 17 (26.6\%) were girls. Most patients $(59.4 \%)$ in this study were in the age range of 5-8 years old. All patient characteristics were matched among the groups (Table 1).

Fracture characteristics both before and after the operation in both groups are presented in Table 2. The maximum follow-up was 66 months and the minimum was 12 months (average 14.9 months). Patients in group I waited approximately 5.33 days for surgery, while patients in group II waited approximately 59.58 days. Patients from group I waited an average of 1.46 days, while patients from group II waited an average of 7.97 days. Minimal functional movement was achieved at the $12^{\text {th }}$ postoperative day. However, one patient did not manage to achieve functional movement. The average elbow flexion one year after the operation was 129.30 degrees. The preoperative minimal Baumann's angle was 2.59 degrees, on average. After the operation, the average angle was 15.77 degrees. The mean humerocapitellar angle was -26.26 degrees preoperatively and 32.55 degrees postoperatively. The average time to bone healing was 40 days for both groups.

After processing the data, there was no statistically significant difference between the groups before surgery (Table 3).

The differences between group I (emergency surgical) and group II (delayed surgical) after surgery are shown in Table 4. The emergency surgical group (group I) successfully accomplished continuous anterior humeral lines and had less frequent myositis ossificans. Functional results and subjective symptoms indicate that there is a highly significant difference between the groups. Patients from group I had significantly better results one year after operation than patients from group II.

\section{DISCUSSION}

Supracondylar fracture of the humerus is the most common elbow fracture in children. It is also one of the

Table 4. Postoperative differences between groups I and II

\begin{tabular}{|c|c|c|c|c|}
\hline & & I & II & $\begin{array}{l}\text { Difference } \\
\text { frequency }\end{array}$ \\
\hline \multirow{4}{*}{ Functional result ${ }^{\#}$} & Poor & 0 & 6 & \multirow{4}{*}{$* *$} \\
\hline & Satisfactory & 1 & 11 & \\
\hline & Good & 1 & 16 & \\
\hline & Excellent & 24 & 5 & \\
\hline \multirow{2}{*}{$\begin{array}{l}\text { Continuous anterior } \\
\text { humeral line }\end{array}$} & No & 2 & 12 & \multirow{2}{*}{$*$} \\
\hline & Yes & 24 & 26 & \\
\hline \multirow{2}{*}{$\begin{array}{l}\text { Continuous } \\
\text { coronoid line }\end{array}$} & No & 0 & 4 & \multirow{2}{*}{$\mathrm{p}>0.05$} \\
\hline & Yes & 26 & 34 & \\
\hline \multirow{2}{*}{ Nerve lesions } & No & 23 & 32 & \multirow{2}{*}{$\mathrm{p}>0.05$} \\
\hline & Yes & 3 & 6 & \\
\hline \multirow{2}{*}{$\begin{array}{c}\text { Vascular } \\
\text { complications }\end{array}$} & No & 26 & 37 & \multirow{2}{*}{$\mathrm{p}>0.05$} \\
\hline & Yes & l & 1 & \\
\hline \multirow{2}{*}{ Myositis ossificans } & No & 24 & 27 & \multirow{2}{*}{$*$} \\
\hline & Yes & 2 & 11 & \\
\hline \multirow{2}{*}{ Cubitus varus ${ }^{\#}$} & No & 25 & 31 & \multirow{2}{*}{$\mathrm{p}>0.05$} \\
\hline & Yes & 1 & 7 & \\
\hline \multirow{2}{*}{ Cubitus valgus $^{\#}$} & No & 25 & 38 & \multirow{2}{*}{$\mathrm{p}>0.05$} \\
\hline & Yes & 1 & l & \\
\hline \multirow{2}{*}{$\begin{array}{l}\text { Subjective symp- } \\
\text { toms }\end{array}$} & No & 25 & 17 & \multirow{2}{*}{$* *$} \\
\hline & Yes & 1 & 21 & \\
\hline Baumann's angle & & 17.77 & 14.39 & $*$ \\
\hline $\begin{array}{c}\text { Humerocapitellar } \\
\text { angle }\end{array}$ & & 37.15 & 29.58 & $* *$ \\
\hline $\begin{array}{l}\text { Extension } \\
\text { movement }^{\#}\end{array}$ & & -1.15 & -10.66 & $\because *$ \\
\hline Flexion movement ${ }^{\#}$ & & 135.4 & 125.1 & $* *$ \\
\hline
\end{tabular}


most difficult fractures to treat (15). Fracture is more common in boys (Table 1); this is explained by the fact that boys are more restless than girls (16). Despite the high incidence, we still do not have a generally accepted treatment for this fracture. Because of this, the aim of this study was to evaluate whether delayed or immediate surgical treatment has an advantage in the treatment of supracondylar fractures in children.

Patients in both groups showed excellent functional results, but this rate did not exceed $50 \%$ (Table 2). This result was expected, given the complexity of treatment. Postoperative establishment of continuous anterior humeral and coronoid lines shows the success of surgical treatment. The percent and number of vascular complications was similar to the literature data $(17,18)$. Myositis ossificans is an indicator of damaged soft tissue around the elbow and is associated with poorer functional outcomes. The presence of myositis ossificans was higher than that in the available literature (19). Cubitus varus and cubitus valgus describe elbow deformities one year after operation. Based on the results, we can see that approximately $13 \%$ of all patients exhibited observed deformities (Table 2). At the end of follow-up $34.4 \%$ of patients reported subjective symptoms. Symptoms are not categorized by their character. However, patients mainly complained of pain in the elbow during meteorological changes.

Before operation we examined the continuity of the humeral and coronoid lines, nerve lesions and vascular complications as well as the Baumann's and humerocapitellar angle because these parameters are indicators of operative success. The results showed that there were no preoperative differences between the groups (Table 3).

Differences between the emergency surgical (group I) and delayed surgical cohorts (group II) are presented in table 4. Functional results of elbows one year after operation were better in group I. These results are in agreement with previously presented literature data (20-22, 8). Twenty-four patients from group I had excellent functional results, while only 5 patients from group II showed the same functional results. Unfortunately, there are few similar studies which investigated this type of fracture in children. Research performed by Bojovic and co-workers found that good results were achieved by treating patients (with open and closed reposition) within the first twelve hours after fracture (22). Additionally, in a prospective study of 93 children, Ducic and co-authors recommended a selective approach to the initial treatment of displaced supracondylar fractures in children based on fracture subtype. They also recommended that closed reduction should always be attempted first (23).

Postoperatively, 2 patients from group I and 12 patients from group II did not have established continuity of the anterior humeral line. Statistics indicate successful postoperative reposition in the sagittal plane among the emergency surgical group (group I). However, the available literature does not have enough data regarding this parameter. Postoperatively, the rates of continuous coronoid lines, nerve le- sions and vascular complications were similar between the groups. Frequency data were correlated with data from the available literature $(24,25)$. Based on these results, we can say that the operative technique in both groups was good, with anatomical repositioning of the fragments. Myositis ossificans, an indicator of soft tissue damage, occurred more frequently in group II than in group I. This parameter is very important, as it can lead to the formation of large ossifications that block movement of the elbow. Cubitus varus and cubitus valgus are described as cosmetic deformities with little functional significance, including chronic pain, snapping elbow and increased risk of lateral condyle and other secondary fractures (5). Differences between groups in these parameters were not recorded. There were 8 patients with cubitus varus, 1 patient from group I and 7 patients from group II. We also found a highly significant difference in the presence of subjective complaints one year after surgery between groups. Twenty-one patients from group II complained of subjective symptoms while only 1 patient from group I had similar complaints, but the available literature has not considered this parameter. The value of Baumann's angle after surgery was within the physiological range in all patients. However, there was a statistically significant difference between the groups. Better results were achieved with the humerocapitellar angle. Furthermore, extension and flexion movements in group I suggest that emergency surgical treatment of SCHF results in is better and faster rehabilitation. However, several limitations to this study need to be acknowledged. The initial choice of treatment was based on the expert opinion of a senior orthopaedic surgeon. Attitudes for or against orthopaedic methods in an injured child were based on personal experiences in interpreting clinical findings or available radiographic data. Considering that these fractures are associated with numerous complications, further investigation should examine different procedures for the treatment of SCHF in larger study samples.

\section{CONCLUSION}

In summary, a statistically significant difference between the functional results and the absence of subjective symptoms after one year of operation in group I suggests that emergency surgical treatment of displaced supracondylar fractures of the humerus is optimal. Furthermore, according to many authors, the difference in the occurrence of myositis ossificans also favours emergency surgical treatment, which is most responsible for poor final results.

\section{REFERENCES}

1. Sutton WR, Greene WB, Georgopoulos G, Dameron TB Jr. Displaced supracondylar humeral fractures in children. A comparison of results and costs in patients treated by skeletal traction versus percutaneous pinning. Clin Orthop Relat Res. 1992; 278:81-7. 
2. Behdad A, Behdad S, Hosseinipour M. Pediatric Elbow Fractures in a Major Trauma Center in Iran. Arch Trauma Res. 2013; 1:172-5.

3. Shrader MW. Pediatric supracondylar fractures and pediatric physeal elbow fractures. Orthop Clin North Am. 2008; 39:163-71.

4. Kocher MS, Kasser JR, Waters PM, et al. Lateral entry compared with medial and lateral entry pin fixation for completely displaced supracondylar humeral fractures in children. The Journal of Bone \& Joint Surgery. 2007; 89:706-12.

5. Zorrilla S de Neira J, Prada-Cañizares A, Marti-Ciruelos R, Pretell-Mazzini J. Supracondylar humeral fractures in children: current concepts for management and prognosis. Int Orthop. 2015 Aug 28. [Epub ahead of print].

6. David L, Skage, John M, Flynn. Supracondylar fractures of the distal humerus. In: James H, Beaty, James $\mathrm{R}$, Kasser,. editors. Rockwood and Wilkins Fractures in children. 7th ed. Lippincott; 2010. pp. 488-523.

7. Omid R, Choi PD, Skaggs DL. Supracondylar humeral fractures in children. J Bone Joint Surg Am. 2008; 90:1121-32.

8. Sarrafan N, Nasab SA, Ghalami T. Treatment of displaced supracondylar fracture of the humerus in children by open pining from lateral approach: an investigation of clinical and radiographical results. Pak J Med Sci. 2015; 31:930-5.

9. Liu SP, Zhao J, Li G, Lin B, Liu Y. Treatment of humeral supracondylar fracture in children with external plaster fixation on extension position. Zhongguo Gu Shang. 2015 ; 28:743-6.

10. Wolfswinkel EM, Weathers WM, Siy RW, Horowitz KS, Hollier LH Jr. Less is more in the nonoperative management of complete brachial artery transection after supracondylar humeral fracture. Ann Vasc Surg. 2014; 28:739.e11-6.

11. Ladenhauf HN, Schaffert M, Bauer J. The displaced supracondylar humerus fracture: indications for surgery and surgi- cal options: a 2014 update. Curr Opin Pediatr 2014; 26:64-9.

12. Moraleda L, Valencia M, Barco R, Gonzalez-Moran G. Natural history of unreduced Gartland type-II supracondylar frac- tures of the humerus in children: a two to thirteen-year follow-up study. J Bone Joint Surg Am. 2013; 95:28-34.
13. Mulpuri K, Hosalkar H, Howard A. AAOS clinical practice guideline: the treatment of pediatric supracondylar humerus fractures. J Am Acad Orthop Surg. 2012; 20:328-30.

14. Hardacre JA, Nahigian SH, Froimson AI, Brown JE. Fractures of the lateral condyle of the humerus in children. J Bone Joint Surg Am. 1971; 53:1083-95.

15. Abzug JM, Herman MJ. Management of supracondylar humerus fractures in children: current concepts. J Am Acad Orthop Surg. 2012; 20:69-77.

16. Kang S, Kam M, Miraj F, Park SS. The prognostic value of the fracture level in the treatment of Gartland type III supracondylar humeral fracture in children. Bone Joint J. 2015; 97-B:134-40.

17. Kasser JR. Location of treatment of supracondylar fractures of the humerus in children. Clin Orthop Relt Res. 2005; 434:110-3.

18. Luria S, Sucar A, Eylon S, et al. Vascular complications of supracondylar humeral fractures in children. Journal of Pediatric Orthopaedics B. 2007; 16:133-43.

19. Shah ZA, Arif U. Displaced supracondylar humeral fractures. Professional Medical Journal. 2013; 20:818-24.

20. O'hara LJ, Barlow JW, Clarke NM. Displaced supracondylar fractures of the humerus in children: audit changes practice. Journal of Bone \& Joint Surgery. 2000; 82:204-10.

21. Keppler P, Salem K, Schwarting B, Kinzl L. The effectiveness of physiotherapy after operative treatment of supracondylar humeral fractures in children. Journal of Pediatric Orthopaedics. 2005; 25:314-6.

22. Bojović N, Marjanović Z, Živanović D, Đorđević N, Stojanović M. Suprakondilarni prelom humerusa kod dece.Acta Medica Medianae. 2012; 51(3): 5-12.

23. Dučić S, Bumbaširević $M$, Radlović V,et al. Displaced supracondylar humeral fractures in children: Comparison of three treatment approaches. Srp Arh Celok Lek. 2016; 144(1-2): 46-51.

24. Louahem DM, Nebunescu A, Canavese F, Dimeglio A. Neurovascular complications and severe displacement in supracondylar humerus fractures in children: defensive or offensive strategy? Journal of Pediatric Orthopaedics B. 2006; 15:51-57.

25. Marcheix PS, Vacquerie V, Longis B, Peyrou P, Fourcade L, Moulies D. Distal humerus lateral condyle fracture in children: when is the conservative treatment a valid option? Orthop Traumatol Surg Res. 2011; 97:304-7. 